Laporan Peningkatan Mutu

\title{
PENINGKATAN MUTU PENGGUNAAN ANTIBIOTIK BIJAK MELALUI KESESUAIAN TEMUAN HASIL KULTUR DENGAN KAJIAN RISIKO PASIEN MENURUT MODEL REGULASI ANTIMIKROBA SISTEM PROSPEKTIF (RASPRO)
}

\author{
RONALD IRWANTO NATADIDJAJA ${ }^{1,2}$, HADIANTI ADLANI ${ }^{2}$, HADI SUMARSONO ${ }^{2,3}$ \\ 1'Departemen IImu Penyakit Dalam FK TRISAKTI, Jakarta \\ ${ }^{2}$ RASPRO Indonesia Study Group \\ ${ }^{3}$ Ikatan Apoteker Indonesia
}

Email korespondensi: ronald.irwanto@yahoo.com

Dikirimkan 29 Oktober 2019, Diterima 3 Juli 2020

\begin{abstract}
Abstrak
Masalah Mutu: Standar 4 Kajian SNARS 2018 menyatakan bahwa rumah sakit wajib memiliki surveilens kepekaan kuman terhadap antibiotik. Hal ini harus menjadi dasar pertimbangan pembuatan Panduan Penggunaan Antibiotik (PPAB). Di sisi lain, timbulnya kuman Multi Drug Resistance (MDR) juga dipengaruhi oleh berbagai faktor. Pemberian antibiotik empirik, selain berdasar pada pola kuman, juga sebaiknya mempertimbangkan berbagai faktor risiko timbulnya kuman MDR.

Pilihan Solusi: Regulasi Antimikroba Sistem Prospektif (RASPRO) adalah sebuah model tataguna antimikroba yang disintesis dari berbagai kepustakaan dengan mempertimbangkan berbagai faktor yang dapat menyebabkan timbulnya kuman-kuman MDR pada surveilans kepekaan kuman, sehingga dapat mengarahkan klinisi pada peresepan antibiotik bijak.

Implementasi: Kajian risiko yang dibuat dalam RASPRO menentukan bahwa immunocompromised dan/atau dengan komorbid Diabetes Melitus yang tidak terkontrol atau dengan riwayat konsumsi antibiotik kurang dari 90 hari, dan/atau riwayat perawatan di rumah sakit lebih dari 48 jam dalam waktu kurang dari 90 hari, dan/atau riwayat penggunaan instrumen medis kurang dari 90 hari masuk dalam risiko MDR. Pasien-pasien yang tidak termasuk dalam kategori di atas akan masuk ke dalam prediksi infeksi oleh kuman multisensitif.

Evaluasi dan Pembelajaran: Pada surveilans kepekaan kuman dengan data sekunder diambil dari sebuah rumah sakit swasta tipe B di Jakarta antara tahun 2016-2018, dengan rumus sampel tunggal, didapatkan 106 sampel kultur dari 86 pasien. Terdapat kesesuaian pada 54 dari 57 hasil kultur yang diambil dari pasien dengan kajian risiko infeksi kuman multisensitif (94,74\%). Kesesuaian antara temuan hasil kultur MDR dengan kajian risiko model RASPRO terdapat pada 44 dari 49 kultur (89,80\%), dengan 9 kultur menunjukkan Extended Spectrum Beta-Lactamase (ESBL). Total kesesuaian hasil kultur dengan kajian risiko empirik model RASPRO mencapai 92,45\%. Tingginya persentase kesesuaian temuan kultur kuman penyebab infeksi dengan kajian faktor risiko model RASPRO sepertinya dapat menjadi pertimbangan dalam mengarahkan klinisi dalam pemberian antibiotik empirik spektrum sempit dan luas pada praktek klinis sehari-hari di rumah sakit. Dengan praktik seperti ini kualitas penggunaan antibiotik diharapkan dapat meningkat.
\end{abstract}

Kata kunci: antibiotik, RASPRO, risiko, kultur, Multi-Drug Resistance

\section{Masalah Mutu}

Saat ini resistensi antibiotik menjadi isu global dan menjadi permasalahan di seluruh dunia. Sebuah penelitian pada lima rumah sakit di Denmark dan sebuah rumah sakit di Islandia mendapatkan 30,00\% isolat Methicillin Resistant Staphylococcus epidermidis (MRSE) pada pasien-pasien rawat inap yang kemudian dikaitkan dengan penggunaan instrument medis ${ }^{1}$. Angka resistensi terhadap antibiotika beta-laktam pada individu-individu rawat inap juga ditemukan meningkat ${ }^{2}$. 
Program Pengendalian Resistensi Antimikroba (PPRA) merupakan sebuah program yang dikaji dalam SNARS 20183. Standar 4 SNARS 2018 tentang pelaksanaan PPRA di rumah sakit, menggarisbawahi pentingnya pola resistensi antimikroba yang diambil dari surveilans kepekaan kuman di rumah sakit. SNARS 2018 menekankan pentingnya pemberian antibiotik bijak yang didasarkan pada temuan pola kuman lokal. Hal ini perlu disadari bahwa pembuatan PPAB harus didasari pada surveilens kepekaan kuman33.

SNARS 2018 juga menekankan bahwa rumah sakit wajib membentuk Komite Pengendalian Resistensi Antimikroba (KPRA). KPRA bertanggungjawab untuk pelaksanaan program pengendalian resistensi antimikroba di rumah sakit. Namun, berdasarkan pengamatan, kesulitan menjalankan program tataguna antibiotik oleh KPRA sering kali disebabkan oleh tidak adanya persamaan persepsi antara klinisi sebagai pengguna antibiotik dengan program KPRA dalam memutuskan antibiotik apa yang digunakan untuk pasien. Sebanyak 93,86\% dari 114 rumah sakit yang tersurvei belum menjalankan PPRA, menyatakan bahwa yang dibutuhkan dalam menjalankan PPRA adalah konsep pelaksanaan yang jelas ${ }^{4}$.

Surveilans kepekaan kuman menjadi tulang punggung pelaksanaan PPRA. Berbagai kajian faktor risiko yang dapat mengarahkan klinisi terkait kapan memberikan antibiotik spektrum sensitif (dengan kajian faktor risiko kuman multisensitif sebagai penyebab infeksinya) serta kapan memberikan antibiotik empirik sepektrum luas (dengan kajian faktor risiko kuman MDR sebagai penyebab infeksinya) sangat perlu dilakukan agar pembuatan PPAB peresepan antibiotik empirik di rumah sakit menjadi lebih terarah.

\section{Pilihan Solusi}

Berbagai kepustakaan telah membahas berbagai faktor yang dapat melatarbelakangi munculnya kuman MDR. Regulasi Antimikroba Sistem Prospektif (RASPRO) adalah sebuah model tataguna antibiotik yang dikembangkan dengan tujuan untuk memandu klinisi dalam memberikan antibiotik, kapan menggunakan antibiotik spektrum luas, kapan menggunakan antibiotik spektrum sempit, sesuai dengan faktor risiko yang melatarbelakanginya.

Pada sebuah studi kuasi-experimental model RASPRO, dengan pembuatan $\mathrm{PPAB}$, berdasar surveilans kepekaan kuman lokal dan berbagai faktor timbulnya MDR yang terimplementasi pada peresepan antibiotik empirik awal tercatat penurunan peresepan antibiotik spektrum luas dari 1.339 ampul pada tiga bulan sebelum implementasi, menjadi 320 ampul pada tiga bulan setelah implementasi4. Hal ini sesuai dengan amanah Permenkes 8/2015 pasal 11 butir a, yang menyebutkan bahwa salah satu indikator mutu pelaksanaan PPRA di rumah sakit adalah perbaikan kuantitas penggunaan antimikroba.

Beberapa peneliti telah menyatakan adanya berbagai risiko munculnya kuman MDR yang kemudian membutuhkan peresepan antibiotik spektrum luas. Gambaran kemungkinan pnemonia oleh kuman MDR antara lain apabila terdapat riwayat penggunaan antibiotik atau perawatan lebih dari 48 jam dan kurang dari 90 hari sebelumnya serta berbagai kondisi multipatologi 5,6 .

Assessment of Risk of Multidrug resistant pathogens in Community-onset Pneumonia (ARUC) score menyatakan bahwa kemungkinan terjadinya infeksi MDR pada pnemonia tidak hanya dipengaruhi oleh kondisi Health Care Associated Pneumonia (HCAP), melainkan ada berbagai faktor lain seperti riwayat perawatan di rumah sakit kurang dari 90 hari disertai dengan riwayat pemberian antibiotik kurang dari 30 hari dan perawatan di instalasi kesehatan, disertai dengan infiltrat bilateral, efusi pleura dan penurunan $\mathrm{PaO} 2 / \mathrm{FiO}_{2}$ kurang dari 300 untuk prediksi infeksi MDR pneumonia7. Peneliti lain menuliskan bahwa prediksi MDR pada infeksi saluran kemih harus mempertimbangkan penggunaan antibiotik dalam kurang dari 30 hari terakhir, penggunaan urin kateter, riwayat perawatan kurang dari 30 hari, tindakan invasif kurang dari 30 hari, jenis kelamin laki-laki, serta riwayat infeksi saluran kemih dalam satu tahun terakhir ${ }^{8}$.

Untuk prediksi kuman Enterbactericeae ESBL, Tumbarelo memprediksi infeksi oleh Enterobacteriaceae ESBL memperhitungkan penggunaan antibiotik kurang dari 90 hari, kondisi immunocompromised (Charlson Comorbidity), pasien geriatri, riwayat hospitalisasi dalam satu tahun serta riwayat penggunan instrumen medis (kateter urin) kurang dari 30 hari ${ }^{9}$.

Duke melakukan simplifikasi terhadap kriteria Tumbarelo, dengan mempertimbangkan penggunaan antibiotik kurang dari 90 hari dengan riwayat penggunaan immunospuresan (kondisi immunocompromised) kurang dari 90 hari terakhir disertai dengan riwayat perawatan di rumah sakit kurang dari satu tahun serta penggunaan instrumen medis (kateter urin) kurang dari 30 hari untuk memprediksi infeksi oleh Enterobacteriaceae ESBL9. ESBL pada kriteria Magiorakos masuk ke dalam kategori $\mathrm{MDR}^{6}$. Kajian faktor risiko kuman multisensitif dan kuman MDR pada model RASPRO disintesis dari beberapa kepustakaan di atas.

\section{Implementasi}

Penelitian ini telah mendapatkan persetujuan etik yang dikeluarkan oleh Komite Etik Riset Fakultas Kedokteran Universitas Trisakti, Jakarta nomor: 148/KER/FK/VIII/2019 tertanggal 14 Agustus 2019. Penerapan model RASPRO dalam menjalankan fungsi KPRA di rumah sakit harus diawali dengan menentukan pola kuman dan kajian faktor risikonya. Kajian faktor risiko ini kelak akan digunakan sebagai salah satu dasar pertimbangan pemberian antibiotik empirik, yang mengarahkan kapan klinisi dapat memberikan antibiotik spektrum sempit dan kapan klinisi dapat memberikan antibiotik spektrum luas (dengan kajian faktor risiko kuman MDR sebagai penyebab infeksinya).

RASPRO membuat sebuah terobosan dengan mensintesis berbagai jurnal akademik dan mencoba mengkaji kemungkinan risiko infeksi oleh kuman multisensitif dan kemungkinan infeksi oleh kuman MDR. 
Pada survey ini, kami mencoba menilai kesesuaian kajian faktor risiko model RASPRO dengan temuan kuman multisensitif atau kuman MDR sebagai penyebab infeksi. Survei terbatas ini mencoba menggambarkan persentase ketepatan kuman penyebab infeksi dengan prediksi menurut kajian faktor risiko model RASPRO. Hal ini diharapkan dapat menjadi asupan dalam pembuatan $\mathrm{PAB}$ dan peresepan antibiotik empirik. Dalam praktek sehari-hari, yang dapat mengarahkan kapan klinisi harus memberi antibiotik empirik spektrum sempit dan kapan memberi antibiotik spektrum luas.

Pengambilan sampel dilakukan pada data sekunder status antara tahun 2016-2018. Jumlah sampel yang diambil dari hasil rumus perhitungan sampel adalah 106 kultur dari berbagai spesimen yang diambil dari 86 pasien secara acak dengan consecutive sampling $(\mathrm{p}<0,05)$. Data kultur diambil dari rekam medis yang tercatat lengkap riwayat perawatan dan penggunaan antibiotiknya. Penentuan MDR kuman gram negatif dan gram positif berdasarkan kriteria yang dikemukakan oleh Magiorakos, dikategorikan sebagai MDR apabila kuman resisten terhadap lebih dari atau sama dengan 1 antibiotik pada lebih dari atau sama dengan 3 grup antibiotik ${ }^{10}$.

MDR kuman gram positif termasuk Extended Spectrum BetaLactamase (ESBL), Methicillin Resistant Staphylococcus aureus (MRSA)/Methicillin Resistant Staphylococcus epidermidis (MRSE)/Methicillin Resistant Streptococcus haemolyticus (MRSH). Berdasarkan kriteria tersebut dilakukan perbandingan antara kesesuaian hasil kultur dan kajian risiko pasien sesuai model RASPRO.

\section{Evaluasi dan Pembelajaran}

Pada penelitian ini diperoleh mayoritas subjek berjenis kelamin wanita $(67,44 \%)$. Data pada tabel 2 menunjukkan infeksi infeksi terbanyak diambil dari infeksi saluran kemih (32,08\%), disusul dengan infeksi paru (18,87\%). Sebuah peneltian menunjukkan terdapat $34,50 \%$ isolat MDR terkategori ESBL pada kultur yang diambil dari pasien-pasien di luar rumah sakit. Pertimbangan faktor risiko yang digunakan di sini antara lain adalah riwayat penggunaan antibiotik sebelumnya, riwayat hospitalisasi sebelumnya, usia lanjut (lebih dari 65 tahun) dan jenis kelamin laki-laki ${ }^{11}$.

Di sisi lain, sebuah review menjelaskan bahwa berbagai faktor risiko prediksi infeksi MDR adalah: riwayat kolonisasi MDR, riwayat penggunaan antibiotik sebelumnya, riwayat hospitalisasi, dan adanya komorbiditas dengan tempat infeksi terutama pada daerah luka, penggunaan kateter, plak gigi dan pada subjek dengan gangguan struktur paru ${ }^{12}$. RASPRO mencoba menggunakan kriteria yang lebih sederhana untuk mengkaji kemungkinan infeksi kuman MDR.

Data pada tabel 3 diambil dari 86 subjek dengan 106 kultur. Pengambilan kultur ada yang dilakukan pada pasien yang sama, namun dari saat yang berbeda, sehingga bisa berbeda dari segi kajian faktor risikonya.

Data tersebut juga menunjukkan bahwa sebagian besar penyebab infeksi yang mungkin juga dinyatakan sebagai MDR adalah gram negatif. Hal ini erat kaitannya dengan perkembangan dan penggunaan antibiotik yang akhir-akhir ini cenderung untuk mentargetkan infeksi oleh kuman-kuman gram negatif ${ }^{13}$.

Tabel 3 menunjukkan total kesesuaian temuan kultur dengan kajian risiko model RASPRO yang mungkin lebih sederhana dari yang digunakan pada penelitian Ben-Ami et al dengan mengekslusi kriteria jenis kelamin ${ }^{11}$. Pada tabel ini, secara keseluruhan dapat kita lihat bahwa dari total 106 kultur yang diambil, sebanyak 98 (92,45\%) kultur sesuai dengan kajian risiko model RASPRO sementara 8 kultur lainnya (7,55\%) tidak sesuai.

Tabel 1. Karakteristik Subjek Penelitian $(n=86)$

\begin{tabular}{lcc}
\hline Variabel & n & \% \\
\hline Jenis Kelamin & & \\
$\quad$ Pria & 28 & 32,56 \\
Wanita & 58 & 67,44 \\
Umur & & \\
$18-27$ & 8 & 9,30 \\
$28-37$ & 24 & 27,91 \\
$38-47$ & 14 & 16,28 \\
$48-57$ & 11 & 12,79 \\
$58-67$ & 8 & 9,30 \\
$>67$ & 21 & 24,42 \\
Total & $\mathbf{8 6}$ & $\mathbf{1 0 0 , 0 0}$ \\
\hline
\end{tabular}

Pada Tabel 4 dijumpai kesesuaian hasil kultur dengan kajian risiko pasien model RASPRO untuk kuman multi-sensitif mencapai 94,74\% dari sampel. Kesesuaian prediksi kajian risiko model RASPRO dengan temuan hasil kultur MDR mencapai 89,80\% dari sampel. Kajian risiko model RASPRO mencakup prediksi pasien-pasien dari luar rumah sakit dengan mempertimbangkan berbagai kriteria yang telah dijelaskan sebelumnya yang tidak hanya mencakup kemungkinan kejadian atau riwayat infeksi di rumah sakit saja. Demikian pula pada berbagai penelitian terdahulu, juga menyebutkan bahwa adanya berbagai faktor lain yang menyebabkan MDR tidak lagi hanya dijumpai sebagai penyebab infeksi didapat di rumah sakit, namun juga mulai banyak dijumpai di komunitas ${ }^{14}$.

Tingginya persentase kesesuaian temuan kultur kuman penyebab infeksi dengan kajian faktor risiko model RASPRO, sepertinya dapat dipertimbangkan menjadi sebuah asupan dalam mengarahkan klinisi dalam saat memberikan antibiotik spektrum sempit (dengan kajian faktor risiko kuman multisensitif sebagai penyebab infeksinya) dan saat memberikan antibiotik spektrum luas (dengan kajian faktor risiko kuman MDR sebagai penyebab infeksinya). Pada PPAB kajian faktor risiko RASPRO ini dapat dituliskan sehingga meningkatkan kualitas peresepan antibiotik empirik pada praktek klinis sehari-hari di rumah sakit. 
Tabel 2. Kultur berdasarkan Fokus Infeksi dan Spesimen ( $=106)$

\begin{tabular}{lcclcc}
\hline Fokus Infeksi & $\mathbf{n}$ & $\mathbf{\%}$ & Spesimen & $\mathbf{n}$ & $\mathbf{\%}$ \\
\hline Abses & 4 & 3,77 & Pus & 11 & 10,38 \\
Ulkus & 5 & 4,72 & Swab Nasal dan Tenggorok & 10 & 9,43 \\
ISPA dan Sinusitis & 12 & 11,32 & Feses & 3 & 2,83 \\
Gastroentritis & 3 & 2,83 & Urine & 37 & 34,91 \\
Infeksi Saluran Kemih & 34 & 32,08 & Sputum & 24 & 22,64 \\
Pneumonia & 20 & 18,87 & Ejakulat & 1 & 0,94 \\
Prostatitis & 4 & 3,77 & Sekret Vagina & 16 & 15,09 \\
Infeksi Intra Vaginal & 14 & 13,21 & Darah & 4 & 3,77 \\
Sepsis & 5 & 4,72 & & & \\
Lain-lain & 5 & 4,72 & & & $\mathbf{1 0 6}$ \\
Total & $\mathbf{1 0 6}$ & $\mathbf{1 0 0 , 0 0}$ & Total & $\mathbf{1 0 0 , 0 0}$ \\
\hline
\end{tabular}

Tabel 3. Kesesuaian Temuan Hasil Kultur dengan Kajian Risiko Pasien Menurut Model RASPRO

\begin{tabular}{|c|c|c|c|c|c|c|c|c|c|}
\hline & \multirow{2}{*}{\multicolumn{2}{|c|}{ Multisensitif }} & \multicolumn{5}{|c|}{ MDR } & \multirow{2}{*}{\multicolumn{2}{|c|}{ Prediksi }} \\
\hline & & & \multicolumn{2}{|r|}{ ESBL } & \multicolumn{3}{|c|}{ Non ESBL } & & \\
\hline & $\mathbf{n}$ & $\%$ & $\mathbf{n}$ & $\%$ & $\mathbf{n}$ & & $\%$ & Sesuai & $\begin{array}{c}\text { Tidak } \\
\text { Sesuai }\end{array}$ \\
\hline \multicolumn{10}{|l|}{ Gram Negatif } \\
\hline Acinetobacter sp. & o & 0,00 & o & 0,00 & 4 & & 10,00 & 4 & $\mathrm{o}$ \\
\hline Pseudomanas sp. & o & 0,00 & o & 0,00 & 7 & & 17,50 & 7 & 0 \\
\hline Klebsiela pneumonia & 15 & 26,32 & 2 & 22,22 & 6 & & 15,00 & 21 & 2 \\
\hline Enterobacter sp. & 1 & 1,75 & o & 0,00 & 1 & & 2,50 & 2 & 0 \\
\hline Proteus sp. & o & 0,00 & o & 0,00 & 2 & & 5,00 & 2 & o \\
\hline Providencia stuartii & o & 0,00 & o & 0,00 & 1 & & 2,50 & 1 & o \\
\hline Pantoea agglomerans & 1 & 1,75 & o & 0,00 & o & & 0,00 & 1 & o \\
\hline Raoultella ornithinolytica & o & 0,00 & o & 0,00 & 1 & & 2,50 & 1 & o \\
\hline \multicolumn{10}{|l|}{ Gram Positif } \\
\hline Staphylococcus aureus & 4 & 7,02 & o & 0,00 & 1 & * & 2,50 & 5 & o \\
\hline Staphylococcus epidermidis & 1 & 1,75 & o & 0,00 & 2 & $* *$ & 5,00 & 3 & o \\
\hline Enterococcus faecalis & 4 & 7,02 & o & 0,00 & 2 & & 5,00 & 5 & 1 \\
\hline Enterococcus faecium & 1 & 1,75 & o & 0,00 & 1 & & 2,50 & 1 & 1 \\
\hline Streptococcus sp. & 8 & 14,04 & o & 0,00 & 4 & & 10,00 & 12 & o \\
\hline Staphylococcus sp. & 3 & 5,26 & o & 0,00 & 1 & & 2,50 & 3 & 1 \\
\hline Total & 21 & $\mathbf{3 6 , 8 4}$ & o & 0,00 & 11 & & 27,50 & 29 & 3 \\
\hline T O T A L & 57 & 100,00 & 9 & 100,00 & 40 & & 100,00 & 98 & 8 \\
\hline
\end{tabular}

Tabel 4. Persentase Kesesuaian Hasil Kultur dengan Kajian Risiko Infeksi Multisensitif dan MDR Model RASPRO

\begin{tabular}{lcccccc}
\hline & \multicolumn{2}{c}{ Sesuai } & \multicolumn{2}{c}{ Tidak Sesuai } & \multicolumn{2}{c}{ Total } \\
\cline { 2 - 7 } & $\mathbf{n}$ & $\mathbf{\%}$ & $\mathbf{n}$ & $\mathbf{\%}$ & $\mathbf{n}$ & $\mathbf{\%}$ \\
\hline Multisensitif & 54 & 94,74 & 3 & 5,26 & 57 & 100,00 \\
MDR & 44 & 89,80 & 5 & 10,20 & 49 & 100,00 \\
\hline
\end{tabular}




\section{Referensi}

1. Miragaia M, Couto I, Pereira FFS, dkk. Molecular characterization of methicillin resistant Staphylococcus epidermidis clones: evidence of geographic dissemination. Journal of Clinical Microbiology 2002;40(2):430-8. Doi:10.1128/JCM.40.2.430438.2002.

2. Livermore DM. Management of multiple drugs resistant infection. Journal of Antimicrobial Chemotherapy 2004;54(6):1162. Doi: https://doi.org/10.1093/jac/dkh466.

3. Komisi Akreditasi Rumah Sakit. Standar Nasional Akreditasi Rumah Sakit (SNARS) Edisi 1. Jakarta: Komisi Akreditasi Rumah Sakit; 2018

4. Irwanto R, Widodo D, Ariyani A, dkk. Survey Kebutuhan dan Hambatan Rumah Sakit dalam Menjalankan Fungsi Panitia Pengendalian Resistensi Antibiotik. Journal of Hospital Accreditation 2019;1(2):36-40. Doi: https://doi.org/10.35727/ jha.vii2.

5. Aliberti S, Di Pasquale M, Zanaboni AM, dkk. Stratifying risk factors for multi-drug resistant pathogens in hospitalized patients coming from community with pneumonia. Clin Inf Dis 2012;54(4):470-8. Doi: 10.1093/cid/cir840.

6. Irwanto R. Translasi Antibiogram Kumulatif ke Dalam Bentuk Panduan Penggunaan Antibiotik (PPAB) dan Implementasi Model RASPRO dalam Tataguna Antibiotik di Rumah Sakit. Makalah dipresentasikan pada The 11th Continuing Professional Development on Clinical Pathology and Laboratory Medicine and Medical Equipment EXPO; 201927 Februari-1 Maret:150-157. Surakarta: UNS Press; 2019.

7. Falcone M, Russo A, \& Giannella M. Individualizing risk of multidrug resistant pathogens in community setting pneumonia. PLOS One 2015. Doi: 10.1371/journal pone.0119528.

8. Gomila A, Shaw E, Carratalà J, dkk. Predictive factors for multidrug-resistant gram-negative bacteria among hospitalised patients with complicated urinary tract infections. Antimicrobial Resistance and Infection Control 2018:7:111. Doi: https://doi.org/ 10.1186/s13756-018-0401-6.

9. Johnson SW, Anderson DJ, May DB, dkk. Utility of a Clinical Risk Factor Scoring Model in Predicting Infection with ExtendedSpectrum $\beta$-Lactamase-Producing Enterobacteriaceae on Hospital Admission. Infect Control Hosp Epidemiol 2013;34(4):385-92. Doi: $10.1086 / 669858281$.

10. Magiorakos AP, Srinivasan A, Carey AB, dkk. Multidrug-resistant, extensively drug-resistant and pandrug-resistantbacteria: an international expert proposal for interim standard definitions for acquired resistance. Clinical Microbiology and Infection 2011;18(3):268-281. Doi: https://doi.org/10.1111/j.14690691.2011 $.03570 . \mathrm{x}$

11. Ben-Ami R, Rodrigueze-Bano J, Arslan H, dkk. A multinational survey of risk factors for infection with extended-spectrum betalactamase-producing enterobacteriaceae in nonhospitalized patients. Clin Infect Dis 2009;49(5):682-90. Doi: 10.1086/ 604713 .

12. Drynka P, Niederman MS, El-Solh AA, dkk. Assessment of risk factors for multi-drug resistant organisms to guide empiric antibiotic selection in long term care: a dilemma. American Medical Directors Association 2010:321-5. Doi: 10.1016/j.jamda. 06.012 .

13. Kollef MH, Golan Y, Micek ST, dkk. Appraising Contemporary Strategies to Combat Multidrug Resistant Gram-Negative Bacterial Infections-Proceedings and Data from the GramNegative Resistance Summit. Clinical Infectious Diseases 2011;53(S2):S33-S55. Doi:10.1093/cid/cir 475.

14. Pop-Vicas AE, D'Agata EMC. The Rising Influx of MultidrugResistant Gram-Negative Bacilli into a Tertiary Care Hospital. Clin Inf Dis 2005;40:1792-8. Diakses dari: https://pdfs.semantic scholar.org/357a/d230191133feae9c4e4ed52736de92acdf20.pdf. 